\title{
Implementation of Inclusive Education Model in Primary School at Serang City
}

\author{
Hunainah \\ Lecturer, Iain Sultan Maulana Hasanuddin Banten \\ Banten, Indonesia \\ E-mail: hunianah.syam@gmail.com
}

Received: May 28, 2017 Accepted: July 4, 2017 Published: July 14, 2017

doi:10.5296/ijld.v7i3.11542 URL: https://doi.org/10.5296/ijld.v7i3.11542

\begin{abstract}
This research try to describe the effectiveness of special education provision by inclusion model in public elementary schools in the city of Serang after Permendiknas in 2009 by analyzing the effectiveness of tutoring on classifications of Children with Special Needs, factors supporting the effectiveness of tutoring children with special needs in inclusive schools. This study used a qualitative descriptive design. This design has much similarity with quantitative descriptive design. This study using purposive sampling, which the sampling technique with particular consideration or define groups of participants who become informants in accordance with the selected criteria that are relevant to the research problem. The results showed that: First, the implementation of Inclusive Education after Permendiknas 70 In 2009 in Serang City has not run according to applicable regulations. Second, the availability of a tutor Especially for Children with Special Needs in Elementary School of Serang City is unfavorable category. Third, the availability of special services space for children with special needs in Elementary School at Serang City is categorized not good. Fourth, the effectiveness of tutoring services for children with special needs in Serang City Elementary School is still not good enough.
\end{abstract}

Keywords: Implementation, education, inclusive, Serang City 


\section{Introduction}

\subsection{Background of Problems}

As citizens of the nation, especially educated people realize that getting a decent education is one of fundamental right for every citizen in this country, not least for children with special needs. But the realization of its rights face many obstacles. Among the obstacles are the negative social views, constraints of disability, economic limitations of parents, location at remote/isolated area, and lack of commitment of related stakeholders.

Efforts to resolve these obstacles actually has been done by the government. For example juridically our country has made laws and regulations start from the Laws of 1945 of the amendment, Law on National Education System, up to regulation of minister. In line with the laws and regulations, the government has organized regular schools for normal children and non-regular school for children with special needs such as part-time special education classes of, full-time special education or special schools (segregation). Education for Children with Special Needs using segregation model is intended in order to every citizen has the same right to obtain special education services quality.

However, Heller's research, Holtman \& Messick (1982) showed that the classification and placement of children with disabilities in school, classroom or a special place to be ineffective and discriminative. This study recommends that special education using segragative is only given limited base on a proper identification. Unfortunately, the study does not explain whether all types of Children with Special Needs are not effective following the special education model of segregation? or just some kind of Children with Special Needs such as mental retardation and low mental disorder ineffective with segregation model? Are the causes of the ineffectiveness of segregation similar for all types of Children with Special Needs ? To find these answers, further research needs to be done.

Learning from the ineffectiveness of the segregation model_if proven 'right' it is need to be undertaken in-depth study on the effectiveness of implementation of the inclusion model that began in 2003 was held in some regular schools especially at primary school level. This is in line with the statement of Sapon-Shevin (O Neil, 1995) that inclusive education as a system of educational services requires the existence of school restructuring, so that it becomes a community that supports the fulfillment of the specific needs of each child.

Inclusive education for children with special needs and gifted and outstanding children (ABLB) is an implementation of the Regulation of the Minister of National Education No. 70 of 2009. In accordance with the regulation, regency/municipal government appoint at least one primary school and one secondary school in each districts and one secondary school to implement inclusive schools that required to accept students who have the disorder and have intelligence and special talents.

Data of Center for Special Education Services Education Department of Banten Province in the end of 2012 recorded approximately 99 inclusive schools in elementary, junior and senior high schools spread across eight cities/regencies in Banten Province. If seen from the number of districts in Banten province, that number has not been represented and not evenly 
distributed in all districts in the province of Banten. It's certainly become a concern among related stakeholders to encourage for a mandate of regulation No. 70 of 2009 is implemented according to the rules.

For the government to increase the number of school inclusion would not be difficult because it may designate or establish regular school belonging to the government to become inclusive schools. But public expectations are not limited to increasing the number (quantity) according to the rules, the more important is the issue of quality (quality) and sustainability of inclusive schools in providing special education services for children with special needs. The findings on observations and interviews about the effectiveness of the implementation of special education for children with special needs inclusion in two schools in Serang city concluded that implementation of inclusive education is less effective for several reasons, among them; the limitations of competent teachers, facility limitations, lack of budget and the support of local government.

\subsection{Research Objectives}

This study try to describe the effectiveness of special education provision of inclusive model in public elementary schools in Serang city after education regulation in 2009 to analyze the effectiveness of tutoring seen from the type or classification of children, the factors that supporting the effectiveness of tutoring children with special needs in inclusive schools.

\section{Research Methodology}

\subsection{Place and Time of Research}

This study was conducted at ten primary schools designated as organizer school of inclusive program in Serang city, Banten Province. Two Elementary School located in the District Cipocok and eight others are in the district of Serang. As for the time of the research was conducted in August-October, 2013.

\subsection{Research Methods}

This study used a qualitative descriptive design. This design has much similarity with quantitative descriptive design, because descriptive qualitative usually named the quasi-qualitative design. This study aims to describe, summarize a variety of conditions, situations, or various phenomena of social reality as object of research ... ".

Obviously this method is intended to reveal the data on how the effectiveness of tutoring services for children with special needs in inclusive schools at Serang city seen from (1) the availability of teacher/special counselors; (2) the availability of a special space for tutoring services, and (3) the implementation of tutoring services for Children with Special Needs in Inclusive elementary school at Serang city.

\subsection{Informant of Research}

This research used purposive sampling, that the sampling technique with particular consideration of data sources or define groups of participants who become informants in accordance with selected criteria that are relevant to the research problem. Referring to both 
opinions, the informant of this study is the principal and classroom teacher in ten primary schools of Serang with Children with Special Needs. Principals and classroom teachers in this research are positioned as a key person because both of them logically regarded possession or control of the information required in the research.

As for the size of the purposive informant (sample) determined on the basis of the saturation theory, it means that new data from the informant no longer bring additional insights to the research question. Next informant will be determined in conjunction with the development of the review and analysis of the results when data collection takes place. In other words, this research also use snowball procedure, it means the informant who've requested information may refer to other people who potentially can contribute or provide information to researcher.

\subsection{Methods of Data Collection and Data Analysis Techniques}

In qualitative research, data collection methods are also at the same time are the methods and data analysis techniques. This study uses unstructured observation (without using guide observation) because the researcher personally able to develop the power of observation of an object under study; free guided interview (interview done freely but remains tied to the main points of the interview) and review documentation. These three method is used as a technique of triangulation, which is a combination of methodologies to understand the phenomenon. Through interviews obtained information in the form of words, sentences and or narration. Observation is used to obtain an overview of the availability of a special service space for tutoring Children with Special Needs and implementation services of tutoring for Children with Special Needs done by teachers either kelasikal or individually. Review of the documentation is done to obtain data about decision either of the relevant Decree or daily notes associated with the inclusive program of elementary school that have been studied. The data on the implementation of tutoring can be seen on a worksheet or workbook of teaching and learning activities of Children with Special Needs.

Analysis and interpretation of data using inductive analysis techniques. Creswell (2012) write down the steps to analyze the data in qualitative research as follows: (1) The raw data (transcription, field data, images and so on); (2) processing and preparing the data for analysis; (3) read the entire of the data; (4) coding the data; (5) connects the themes/descriptions and (6) to interpret the themes/descriptions.

\section{Results and Discussion}

3.1. Implementation of Inclusive Education after Regulation of National Education No. 70 In 2009 in Serang city

In Serang city, currently listed 15 public elementary school which provide inclusive program located in District Serang and District Cipocok. Two primary schools located in the District Cipocok and other thirteen primary school in the district of Serang. List of elementary school which provide inclusive program can be seen in the table 4.1 below.

Based on the data in table 4.1 it appears that the inclusive pilot program in primary schools starting from 2004 to 2008. Seen from the year when inclusion programs start can be 
explained as follows: in 2004 appointed 1 Elementary School is Elementary School Batok Bali District of Serang; 2005 appointed five schools such Elementary School Kebaharan 1, Elementary School Kebaharan 2, Elementary School 9 Serang, Elementary School Serang 21 and Elementary School Cipocok Jaya 1; In 2006 was appointed two schools; Elementary School Karang Tumaritis and Elementary School Limpar Serang; In 2007 was appointed one school; Elementary School Sumber Agung Serang; In 2008 was appointed one school; Elementary School Kaliwadas Serang. The remaining four are Elementary School Cijawa Serang, Elementary School Serang, Elementary School Larangan Serang and SDN Cipocok Jaya 2 is not obtained data at inclusion program begins.

Thus it appears that the inclusive program in Elementary School at Serang City has been started before regulation of national education No. 70 in 2009 released. On the contrary, after 2009, none of the additional appointment of primary school inclusive program providers. This fact is attractive to be discussed primarily related to the reason or legal basis of the education department at Serang city pointed to the Elementary School Serang 15. In researcher opinion, there are two reasons. First, the letter of Director General of Primary and Secondary Education Ministry of National Education No.380/C.C6/MN/2003 on January 20, 2003 containing "Every Regency/City are required to organize and develop inclusive education in at least four (4) schools comprising: elementary school, junior high school, senior high school, vocational school. Second, the provision of subsidies for school education provider of integrated/inclusive in 2004 as shown in the Letter of Agreement Granting Subsidies for School Provider of Integrated/Inclusive on 2004 at Elementary School Batok Bali.

The actual awarding of government subsidy is intended as a stimulant in the implementation of inclusive programs at several schools which designated with the expectation the program can run even subsidy does not exist. But the facts show along subsidies stop, training and coaching in inclusive school are stop. So it can be concluded that the implementation of Inclusive Education before regulation of national education No. 70 In 2009 in Serang city not go well.

If the appointment of inclusive program in the Elementary School Serang stalled until 2008, the next question is how sustainability of 15 (fifteen) Elementary School organizers of inclusive program? Data in 2013 showed that the 15 Elementary School of inclusive organizers, there are six (6) Elementary School that states are still organized inclusive program. Of the six (6) Elementary School, only 3 (three) Elementary School recorded have a special guidance counselor. One teacher claimed many obstacles in giving service to Children with Special Needs at school because there is no special space for handling Children with Special Needs, no tools, and the lack of knowledge in dealing with Children with Special Needs.

Another fact, since the beginning of 2010 the implementation of inclusive education programs in public elementary school stagnate. This is indicated by (1) the absence of appointment of the new Elementary School; (2) a lack of guidance and monitoring of related offices in several inclusive school; (3) the cessation of the activities of the inclusive school of 
communication forum. This was revealed in a statement of some respondents from multiple Elementary School follows: "it has been long time no guidance from relevant agencies, while a teacher who ever get the socialization or training on the implementation of inclusive programs has been moved to another school or to the office."

This condition is very worrying, remembering the initial spirit to provide more humane treatment and non diskrimatif at Children with Special Needs in accessing quality education leads to neglect and obscurity pattern of teaching and learning or tutoring services. Another worrying fact that the presence of the Children with Special Needs in inclusive school has not greeted with joy, on the contrary the presence of the Children with Special Needs to be 'additional burden' for the majority of teachers in inclusive schools. This was revealed in a statement the following respondents: "because we've been designated as the inclusive elementary school, we must accept the Children with Special Needs although in a limited capacity, facilities, tools and so on. The phrase of unpreparedness acceptance of Children with Special Needs at inclusive school for example, "Thank God.. this year, we do not accept Children with Special Needs ".

One year before the rising regulation of national education No. 70 In 2009, Government of Banten Province issued Decree No. 421.2.05/Kep.396-Huk/2008 on the Establishment of the Group Working (POKJA) Development of Model Service in Inclusive Education at Elementary in Banten. The quantity at the provincial level, the decree successfully pointed approximately 100 schools of inclusive program throughout Banten as the attached data. But for Serang city, the Governor's Decree only able to produce one inclusive primary school in Serang city.

Implementation of inclusive education programs at the level of general Primary School in Banten currently not in accordance with the number of districts that 155 districts. In other words, it has been met only $64.5 \%$ of the total districts in Banten. That is, the implementation of Regulation on education system No. 70 of 2009 which mandates that at least one primary school and one secondary school to organize inclusive schools in every district in Banten province has not run as expected.

Implementation of inclusion programs at elementary schools in Serang city in quantity already exceeds the total number of districts that 6 (six) districts. But seen from the distribution of the existence of inclusive school program providers are not evenly distributed in all districts because $87 \%$ is concentrated in the district of Serang and $13 \%$ in district of Cipocok Jaya. That is, there are 4 (four) District in Serang city yet realize Regulation of education system No. 70 in 2009. In other words, in 2008 only 33\% school at Serang city run the the regulation.

\subsection{Availability of Teacher/Special Counselors in Inclusion Primary School of Serang City}

The data in Table 2 of attachment, recorded only 3 Elementary School which has a Special Master Educator, while the other 12 did not have it. In quantity, the availability of special guide counselor in Serang city only $20 \%$, the remaining $80 \%$ of primary school inclusion program providers do not have a special guide counselor. Whereas the presence of special 
teacher for Children with Special Needs in inclusive schools is very important because of its role to determine the success of learning for Children with Special Needs.

Of 3 (three) special counselor teacher in Serang city, only 1 (one) of the teachers according to scientific fields, namely Special Education which in Elementary School Kebaharan 2 Serang. While the two (2) others are not appropriate to their field. Duties as a special counselor teacher automatically attached along with the presence of the Children with Special Needs at the school. Thus, it can be presumed that the degree of readiness to give special service at Children with Special Needs also less than optimal.

On the other hand special counselor teachers in inclusive schools determines the effectiveness of tutoring services for the Children with Special Needs because of the role and duties of the following:

a. Developing educational assessment instrument together with classroom teachers and subject teachers.

b. Building a coordination system between the teachers, the school and parents of students.

c. Implement mentoring of children with disabilities in learning activities together with the classroom teacher/subject teacher.

d. Providing assistance specialized services for children with disabilities may encounter in participating in learning activities in general classes, such as remedial or enrichment.

e. Provide continue guidance and make a special note about children with disabilities for participating in learning activities, which can be understood if teachers change.

f. Providing assistance (experiences) to classroom teacher and/or subject teachers to enable them to provide education services to children with disabilities.

Indeed, until now, mostly primary school teachers have a multi-role, namely as a classroom teacher (teaching several subjects), homeroom teacher, and counselor. The Government recognizes that multi-role teachers of elementary school/ Islamic elementary school in the regular school quite heavy, considering until now, at the primary school level/madrasah not found structural position of counselor. However, in accordance with the level of development of learners of primary school/madrasah, the need for counseling services must remain. To help teachers deal with disruptive behavior learners, there should be a counselor/teacher visits (moving Counselor) who was appointed in each school/madrasah. But these policies are not running, so the service for Children with Special Needs in inclusive schools cannot function as it should.

Ideally, every classroom at inclusive school which there are Children with Special Needs, prepares teacher assistant except teacher of teacher/special counselors. It means in order to services of tutoring can run smoothly for noemal students and Children with Special Needs. 


\section{MInstitute Macrothink $^{m+1}$}

International Journal of Learning and Development

ISSN 2164-4063

3.3. Availability of Special Room of Tutoring Services for Children with Special Needs at SDN Inclusive at Serang City

Based on table 2 in attachment, it appears that none of Elementary School inclusive in Serang city that had a special room for giving services to Children with Special Needs or 0\%. The observation results also showed that handling Children with Special Needs takes place in the classical way in the classroom. If the Children with Special Needs needs special handling, so the Children with Special Needs invited out of the classroom. Place for handling Children with Special Needs individually sometimes take place on the classroom terrace, at teacher's office or in the principal's office.

Unavailability of special palce for the Children with Special Needs in inclusive schools would be second obstacle after absence of professional counselors. Special services place for Children with Special Needs required not only to provide services in learning to individual but also serves as a place of relaxation and intensive therapy.

The data in Table 2 also shows that the type of Children with Special Needs that exist in Elementary School of Serang city is very varied. There are six (6) types of children with special needs, namely:

a. Speech impaired

b. Blind

c. Low mental retardation,

d. Mental disorder

e. Quadriplegic

f. Slow learning such as dysgraphia and dyslexia

To provide adequate service, would not only require specialized service space but will also need the appropriate tools for Children with Special Needs needs. If not, then the inclusive school is just wonderful to hear but 'bitter' perceived for Children with Special Needs. Bitterness and ineffectiveness tutoring services due to the lack of facilities and infrastructure is revealed in the following statement: "Our school ever received tools for Children with Special Needs quadriplegic but because it does not fit then we cannot use it, so that the instrument useless".

The provision of tools for the Children with Special Needs, ideally done in a bottom-up means based on proposals or requests from related school. Provision of tools should be followed by training in its use. Accordingly, the unpreparedness of teacher/special counselors and or teacher assistant in the use of teaching aids for Children with Special Needs can be minimized.

\subsection{Implementation of Tutoring Service for Children with Special Needs at Inclusive Elementary School of Serang City}

Based on data in Table 2 of attachment, carrying 89 Children with Special Needs scattered in 
10 (ten) inclusive school at Serang city. One of 10 (ten) school has a special guidance counselor for the field of science that is PLB, so the chances of Children with Special Needs to get tutoring services in accordance with relative needs are met. But the 9 (nine) others who do not have appropriate teacher/special counselors, can be expected to encounter obstacles so that the implementation of the tutoring service for Children with Special Needs in inclusive school in Serang city could not be implemented as expected.

Services tutoring for Children with Special Needs in school which do not have teacher/special counselors with appropriate science of PLB run as minimally. As stated by one of the inclusive coordinators program in Elementary School Kebaharan 1 Serang that the curriculum used is KTSP and for Children with Special Needs itself is not modified but follow the existing curriculum for normal students. Schools also do not have individual RPP but has specific assessment guidelines for Children with Special Needs. Classroom management model same as regular classroom with normal students in classical way. Children with Special Needs at this school does not have a special service room and has no special media. All facilities (indoor and learning media) are same with normal students.

In the management of infrastructure, Children with Special Needs needs learning tools. One of the Children with Special Needs named Ferdi (unable to speak), he had difficulty in communicating and difficult to understand the lessons described by teachers because of hearing loss and were not given a hearing aid. Ferdi Randinata is an Children with Special Needs, he 11 years old student sitting in class II, he only know numbers and letters but has not been able to read and write yet. One thing that encouraged Ferdi's parents is he has been able to help himself as capable of dressing by himself, bathing and going to school, diligent to go to school, learning the Qur'an and prayer.

To improve the ability of teachers to handle the Children with Special Needs, in the District was created Communication Forum of Inclusive School (FOKSI). In 2007-2009, the Board of FOKSI active in the Group Working of Teacher that formed at the district level. Group Working of Teacher meeting is expected to share experiences and exchange opinions in handling Children with Special Needs at each school. However, as the provision of subsidy for inclusive ceases, then the Group Working of Teacher meeting was halted. Yet, seen from the principal experience of inclusive elementary school organizers program in Serang city just $21 \%$ who had attended the socialization and/or training; $14 \%$ had a comparative study and $7 \%$ ever attended workshop. If the Principal is still very little knowledge about the management of inclusive program, certainly the understanding of teachers will also be minimal. This would affect the effectiveness of tutoring services for Children with Special Needs in Elementary School of Serang city.

Effectiveness of tutoring services for Children with Special Needs in inclusive Elementary School at Serang city can be seen on the sustainability of the inclusive program. Based on data in Table 3 was recorded only 6 Elementary School which is still running, or $40 \%$. It can be concluded that the implementation of tutoring services for Children with Special Needs in inclusion Elementary School at Serang city, in 2013 in ineffective category.

Factors that cause inclusion program is not running include: (1) there is no special 
supervising teacher, (2) there is no cooperation with SKHN 1 Serang, (3) there is no upgrading and dissemination of local education office, (4) turn of principal. When asked the cause of no cooperation with SKH, principal of Elementary School Karang Tumaritis just silent and answered "nothing is close, and the teachers in this school is new comer (in average) because many mutations".

Other causes that obstruct the effectiveness of tutoring services for Children with Special Needs is the difficulty of handling Children with Special Needs. Furthermore, the Supervisor of elementary school stated "I hope there is a special training of the relevant office for teachers organizer in inclusive programs, because in his opinion guidance counselor sometimes overwhelmed moreover subject teachers".

\section{Conclusion}

Based on research result and discussion, it can be deduced as follows: First, the implementation of Inclusive Education after regulation of national education No.70 In 2009 in Serang city has not run according to applicable regulations. It was indicated by the 4 (four) District in Serang city which do not have Inclusive elementary school. Second, the availability of a tutor Especially for Children with Special Needs in Elementary School at Serang City is unfavorable category. This is indicated by the availability number of new GPK about $20 \%$, the remaining $80 \%$ of primary school inclusive program providers do not have a special guide counselor. Third, the availability of space special services for children with special needs in Elementary School at Serang City is categorized not good. This is indicated by none of inclusive Elementary School in Serang city that had a special room to deal Children with Special Needs or 0\%. Fourth, the effectiveness of tutoring services for children with special needs in Elementary School at Serang City is unfavorable category. This is indicated by the numbers the availability of the new teacher/special counselors $20 \%$; Availability of special services space for children with special needs is $0 \%$; lack of tools or learning media; and the absence of individual RPP. Effectiveness of tutoring services for Children with Special Needs in inclusive Elementary School of Serang city recorded only 6 which is still running, or about $40 \%$.

\section{Acknowledgements}

The Author would like to Acknowledgment for contribution of teacher and children Elementary School at Batok Bali, Kebaharan 1, Kebaharan 2, Serang 3, Serang 9, Serang 21, Karang Tumaritis, Limpar Serang, Sumber Agung, Kaliwadas, Cijawa, Larangan and Cipocok Jaya in Serang City, Banten Province, Indonesia.

\section{References}

Alawsilah. (2012). Anyway... Qualitative, Basics Designing and Conducting Qualitative Research. Bandung: Pustaka Jaya.

Amelia et al. (2013). Reports Observations and interviews on the Effectiveness of the Implementation of Special Education, the group of 5th semester student, majoring in PGMI-B Faculty of tarbiyah IAIN "SMH" Banten in 2013. 


\section{Macrothink}

International Journal of Learning and Development

ISSN 2164-4063 2017, Vol. 7, No. 3

Bandi, D. (2006). Learning for Children with Special Needs. Bandung: Refika Aditama.

Budiyanto, et al. (2011). Training of Trainers Module for Inclusive Education. Jakarta: Ministry of National Education.

Burhan, B. (2011). Qualitative Research of Communications, Economics, Public Policy, and Social Studies. Jakarta: Kencana Prenada Media Group.

Chaplin, J. P. (2004). Complete Dictionary of Psychology, translators Kartini Kartono. Jakarta: PT. RajaGrafindo Persada.

Creswell. (2012). Research Design of Approach Qualitative, Quantitative and Mixed. Yogyakarta: Pustaka Pelajar.

Echols, J. M. \& Shadily, H. (n.d.). An English-Indonesian Dictionary.

Hunainah. (2013). Escorting the Handling Program of ABK in Banten, delivered at workshop of Handling Model of ABK in Banten on May 30th, 2013. Papers. Not published.

I.G.A.K. Wardana, et al. Introduction to Special Education.

Ilun Muallifah, et al. (2008). 14 packages of Service for Children with Special Needs. Learning Assistance Program for Islamic School in PGMI.

Kresno, M. (2003). Paper presented at the workshop on Handling Model of ABK in Banten, on May 30th, 2003, unpublished.

Moh. E. (2006). Introduction of Psikopedagogik children with disabilities. Jakarta: PT. Bumi Aksara

Moleong, L. J. (2012). Qualitative Research Methodology. Bandung: Remaja Rosdakarya

Neng, I. et al. (2012). Reports of Observations and Interviews on Effectiveness of the Implementation of Special Education, the group of 5th semester student, majoring in PGMI-B Faculty of tarbiyah IAIN "SMH" Banten in 2013.

Prayitno, \& Ermananti. (1999). Fundamentals of Guidance and Counseling. Jakarta: Rineka Cipta.

Sugiyono. (2006). Quantitative Research Methods, Qualitative and $R \& D$. Bandung: Alfabeta.

Sutjihati Somantri, T. (2006). Psychology of Extraordinary Children. Bandung: Refika Aditama

Amendment of Government Regulation 1945

Government Regulation No. 20 in 2003 on National Education System

Government Regulation No. 23 in 2002 on Child Protection

Government Regulation No. 4 in 1997 on People with Disabilities 


\section{Macrothink}

International Journal of Learning and Development

ISSN 2164-4063 2017, Vol. 7, No. 3

Regulation of the Minister of National Education No. 70 in 2009 on Inclusive Education of Children with Special Needs, Gifted, and Extraordinary.

Signs of Implementation Guidance and Counseling in Line of Formal Education. (2007). Jakarta: Ministry of National Education.

Letter from the General Director of Primary and Secondary Education No. 380 / C.C6 / MN / 2003.

Document from Service Center for Special Education (BPPK) Education Office at Banten Province in 2012

Reports on observations and interviews about the effectiveness of special education provision by the group of 5th semester student, majoring in PGMI-B Faculty of tarbiyah IAIN "SMH" Banten in 2013, Amelia et al. January 10th, 2013 at the SD Negeri Kebaharan 1 Serang city.

\section{Copyright Disclaimer}

Copyright for this article is retained by the author(s), with first publication rights granted to the journal.

This is an open-access article distributed under the terms and conditions of the Creative Commons Attribution license (http://creativecommons.org/licenses/by/4.0/). 